\title{
Education in Russian Higher Education Institutions: an International Character
}

\author{
Vladislav Alekseev ${ }^{1}$, Inessa Arestova ${ }^{1, a^{\star}}$, Evgenia Sharonova $^{1}$, \\ Marina Kupriyanova ${ }^{1}$ \\ 1 Chuvash State Pedagogical University named after I. Y. Yakovlev, 42800038 Karl Marx str., \\ Cheboksary, Russia \\ anessizz@rambler.ru \\ ${ }^{*}$ Corresponding author
}

Keywords: foreign students; motivation; adaptation; higher education; pedagogical university

\begin{abstract}
The paper focuses on the motives for acquiring knowledge from foreign students in a pedagogical university and the quality and dynamics of foreign students' adaptation to the educational environment. A survey was conducted among foreign students studying at the Faculty of Natural Sciences of the Chuvash State Pedagogical University named after I. Y. Yakovlev located in Cheboksary, the Republic of Chuvashia, Russia. The methodology was used to diagnose the learning motivation of students, and a survey was conducted in order to identify the socio-pedagogical conditions for the adaptation of students in high school. Leading motives have been established that determine the desire of foreign students to obtain higher education in Russian cities. The dynamics of changes in students' learning motivation have been also revealed.
\end{abstract}

\section{Introduction}

The modern education system in Russia is being seriously reformed in order to improve the quality of educational services. It should be noted that in recent years there has been a significant increase in the number of students from among foreign citizens. Researchers associate this fact with the active entry of education into the Bologna process and the transition to the contractual form of training specialists [1], [2], [3]. The fact that Russia joined the Bologna process increased the demand from citizens of foreign countries for Russian higher education and, as a result, led to an increase in the number of foreign students in Russian universities [4], [5], [6].

The statistics state that in Russia the number of universities in which foreign students are studying is approaching eight hundred [7]. At the same time, in the process of integrating Russian education into the world educational space, not only large metropolitan educational institutions, but also small provincial are important to analyze. It must be emphasized that bringing education to the international level has become an element of the development strategy of many educational institutions around the world [8], [9]. However, many researchers have noted both the positive and negative aspects of this process [10], [11], [12].

The Chuvash State Pedagogical University named after I. Y. Yakovlev is no exception. Today, more than 390 foreign students study at the university. It should be noted that the overwhelming majority of students come from the countries of Central Asia. For successful integration of foreign students into the educational environment of a pedagogical university, it is necessary to take into account their motivation to receive education in Russia, and it is necessary to develop new approaches to educational activities taking into account the internationalization of higher education [13], [14].

Based on the above, the purpose of the study was, first, to determine the motives of foreign students for getting education in a pedagogical university; second, the assessment of the quality and dynamics of their socio-pedagogical adaptation is another priority in our research.

\section{Materials and methods}

To determine the motives for receiving education, as well as to study the features of quality and dynamics of social and pedagogical adaptation to the educational environment of a university for foreign students, we 
conducted an anonymous survey of foreign students of 1-3 courses (getting a major in Pedagogical Education at the Faculty of Natural Science of the Chuvash State Pedagogical University named after I. Y. Yakovlev. All the interviewed students arrived to study from Turkmenistan. Of all the respondents, 31 students are boys, 25 are girls, age is from 18 to 33 years. The absolute majority of foreign students have a level of proficiency in Russian sufficient to work with the questions presented.

Foreign students were asked to evaluate the significance for each respondent of the cited motives for learning activities on a 5-point system, according to the methodology for diagnosing the learning motivation of students [15]. To study the features of quality and dynamics of social and pedagogical adaptation to the educational environment of a university for foreign students, we developed a questionnaire based on questions affecting interpersonal relations in the system "student - student", "student - teacher", "student study group", "student - university management", as well as issues affecting cultural and living conditions.

\section{Literature Review}

The increase in the number of students who came to receive higher education in Russia from the countries of near and far abroad actualizes the problem of the adaptation of foreign students to educational activities at universities in Russia. Upon arrival in Russia, most of them face a completely unfamiliar and sometimes alien, legal, social, didacti,c and ethnocultural environment [16].

Undoubtedly, to the listed difficulties that foreign students may encounter are added problems of adaptation to new climatic and living conditions. Separation from friends and relatives can also contribute to the emergence of disadaptation, which ultimately can lead to a decrease in the quality of education [17].

The successful integration of foreign students into the educational process and the educational environment of the Russian higher education system requires consideration of not only their adaptation to the educational environment, but also the motivational component of their educational activities.

A person's high intellectual level does not guarantee him high achievements in life. Only the presence of a strong motivation for these achievements will allow all ambitions to come true. Many researchers note that with the dominating motivation to achieve success, a person can achieve the maximum result [18], [19].

Studies have shown that the adaptation of those students who came from other countries to the conditions of the educational environment is not limited to their adaptation only to the educational process. The success of training depends on how they adapt to new living conditions, social environment, norms of social behavior, etc. At the same time, many researchers note that the most significant aspects of the life and social activities of foreign students are the social, socio-communicative, and socio-cultural components, which makes it possible to distinguish these elements as basic in adapting students to the educational environment of the university [20], [21].

\section{Results}

The method used by us to diagnose educational motivation of foreign students allows us to combine statements that characterize the motives of the study in 7 groups: communication and professional motives, creative self-realization, and failure avoidance motives, as well as educational and cognitive, and social motives, along with prestige motive.

Processing the results of the survey showed that the leading motives, its importance expressed in points (minimum - 1 point, maximum - 5 points), change from junior to senior courses (Table 1). It is established that the motives belonging to the group "Communicative" are most significant for first-year students, and become less significant for older students. The motives belonging to the "Professional" group from the fifth and fourth positions of first-year and second-year students, respectively, come to the fore in senior courses. The group of motives "Creative self-realization" is associated with the desire to express themselves, and these motives are more important, mainly for second and third year students.

The motives belonging to the group "Avoiding failure" are characteristic of the first-year students, but retreat to the senior courses. It is noted that the motives from the "Educational and Cognitive" group have unstable dynamics: if in the first year they occupy only the sixth position, then by the second course, the desire to learn new things increases, and then we again see some decrease in the importance of educational 
and cognitive motives. The group of motifs "Prestige" has a fairly stable dynamics, taking middle positions throughout the study. The importance for the first-year foreign students of motives belonging to the group "Social motives" was also noted. It should be noted that they subsequently remain stable in importance.

TABLE 1. AVERAGE VALUES IN POINTS AND PLACE OF THE STUDIED MOTIVES OF FOREIGN STUDENTS ON THE RESULTS OF THE SURVEY.

\begin{tabular}{|c|l|l|l|l|l|l|l|}
\hline \multirow{2}{*}{ No } & \multirow{2}{*}{ Scale of motives } & \multicolumn{6}{|c|}{ Average values in points and place of motives } \\
\cline { 3 - 8 } & & \multicolumn{2}{|c|}{$\mathbf{1}$ course $(\mathbf{n = 1 3})$} & \multicolumn{2}{c|}{$\mathbf{2}$ course $(\mathbf{n = 2 2})$} & \multicolumn{2}{|c|}{ 3 course (n=21) } \\
\cline { 3 - 8 } & Points & Place & Points & Place & Points & Place \\
\hline 1 & Communicative & 3,35 & 2 & 3,05 & 6 & 3,43 & 5 \\
\hline 2 & Professional & 2,99 & 5 & 4,14 & 4 & 3,77 & 1 \\
\hline 3 & $\begin{array}{l}\text { Creative self- } \\
\text { realization }\end{array}$ & 1,92 & 7 & 4,54 & 1 & 3,50 & 2 \\
\hline 4 & Avoiding failure & 3,94 & 1 & 2,83 & 7 & 2,35 & 7 \\
\hline 5 & $\begin{array}{l}\text { Educational and } \\
\text { cognitive }\end{array}$ & 2,49 & 6 & 4,27 & 2 & 3,36 & 6 \\
\hline 6 & Prestige & 3,06 & 4 & 4,12 & 5 & 3,48 & 4 \\
\hline 7 & Social & 3,18 & 3 & 4,25 & 3 & 3,49 & 3 \\
\hline
\end{tabular}

Analysis of the questionnaires developed by us for foreign students in order to assess the quality and dynamics of their social and pedagogical adaptation to the educational environment of the university showed that the absolute majority of respondents $(98.0 \%$ of first-year students, $91.7 \%$ of second-year students, and $84.6 \%$ of third-year students) noted a high degree of accessibility for communication both of the dean and of the dean's office as a whole.

When evaluating the work done by the university management by foreign students, the majority of respondents (76.9-90\%) noted the fact that the management always helps, shows attention and care when applying. Also, $85.0 \%$ of first-year students, $80.6 \%$ of second-year students, and $98.0 \%$ of the third one noted that teachers were always ready to come to their aid if they have difficulties with perceiving educational material, and they are friendly to them. However, we have identified several problems that arise for foreign students in the process of adapting to the educational process.

More than half of the foreign students of all surveyed courses (53.8-58.8\%) said they had difficulty understanding and taking notes on the lecture material; $60.7 \%$ of first-year students, $52.9 \%$ of second-year students have difficulty making presentations, and $38.5 \%$ of third-year students have difficulty in doing homework on their own. At the same time, on average, $85.9 \%$ of respondents point out difficulties when it comes to mastering the material in the disciplines of the natural science block.

On the traditional, in similar studies, the question, "What would you do to make it easier for a foreign student to study?", the overwhelming majority (90.0-76.9\%) answered that they would like to receive individual lessons in the Russian language. And more than half (52.9\%) of third-year students wanted to study individually in some disciplines of the curriculum. Most of the surveyed foreign students $(60.18 \%)$ found it difficult to get used to the long frost period.

It was revealed that the greatest difficulties in nutrition arise upon arrival in Russia, at first, and after the time of particular difficulties in nutrition among the respondents did not arise - problems were noted by no more than $5.9 \%$, foreign students interviewed.

Many foreign students point out that they are experiencing hard separation from their relatives and friends, there were more than $70 \%$ of them in the first year, $53 \%$ in the second year, and $35.3 \%$ in the third. year

It is noted that, on average, $45.6-58.8 \%$ of foreign students have debts to study, while the absolute majority of respondents say that difficulties are mainly due to absenteeism, because it is difficult to get up early in the morning.

To the question "When you arrived in Russia, what was the most difficult thing to get used to?" more than 35\% answered in the following way: "To the living conditions in the hostel." Among the main reasons 
noted by foreign students are the following: strict access control; noise; accommodation for several people in one room; low temperature in the rooms in winter. At the same time, it is gratifying to note that none of the respondents complained of poor sanitary conditions.

The university has students from many nationalities, and the absolute majority of the respondents positively evaluated it (82.9\%). It was revealed that about $70 \%$ of first-year and second-year foreign students experience material difficulties, while only $35.29 \%$ were at the senior courses. When answering the question "For what expenses they lack money first of all," the first-year students (35.4\%) answered that they bought food, $15.8 \%$ of second-year students said "spending on recreation and entertainment," and third-year students indicated the costs of communication (telephone, Internet) and the purchase of clothes and shoes.

When answering the question "To whom they first turn for help in matters of study?", $53.8 \%$ of the first and second year students answered that they were compatriots, and the majority of senior students $(58.82 \%)$ would turn first to the group supervisor and only then to their group mates $(47.06 \%)$.

If at junior courses (especially at the first), a significant part of students (55.3-45.2\%) notes that the educational process is overloaded with classes. By their third year, $88.24 \%$ of respondents noted that, in their opinion, they need to allocate more hours to do their work.

In order to facilitate the adaptation of foreign students to the educational environment of the university, they are actively involved in mass cultural and sporting events held at the university. The vast majority of respondents $(86.4 \%)$ indicated that they were happy to participate in them. On average, $82.6 \%$ of all interviewed foreign students noted a high level of the educational process. At the same time, theoretical training was especially appreciated. On average, $75.8 \%$ of foreign students noted that the existing organization of the educational process contributed to the acquisition of knowledge and helped to assess their individual abilities.

Less than $30 \%$ of the students surveyed believe that the practical and applied knowledge and competencies of the faculty were sufficient, and more than $17 \%$ considered that they were not sufficient. More than $30 \%$ of first-year students, $30.8 \%$ of second-year students, and $41.2 \%$ of third-year students confirmed the correctness of their choice of future profession. The fact that students in the learning process began to better represent their future professional activity was expressed by $30.8 \%$ of first and second year students, by the third year the number of such students was already $56.2 \%$.

\section{Discussions}

Despite the fact that the absolute majority of foreign students quite tolerably communicate in Russian in everyday life, the majority of foreign students of all courses have difficulty of understanding and taking notes of the lecture material, when making presentations and doing homework.

The main role in the problems of understanding and taking notes of the lectures held at the university, in our opinion, is played by an insufficient knowledge of Russian, primarily because of the terminology used in natural science disciplines. A similar problem is noted in technical universities [22]. Therefore, teaching future students the Russian language at the preparatory courses must take into account not only the fact that the Russian language is foreign to them, but also the profile of a future student, as well as how to predict and prevent the difficulties of using special terminology [23].

The experience of foreign students about separation from their relatives and friends is related to the fact that among the respondents there are a lot of students who are enough adults who have served in the army and left not only their parents but also their wives and children in their home country, which distinguishes them from local students entering universities right after graduation.

A large percentage of students who noted difficulties with the need to get up early in the morning, in our opinion, are due to the timing when the survey was conducted-December. There was only one sunny day in Cheboksary for the whole December 2017 (which was in our survey period), and the light period did not exceed more than seven hours a day.

The fact that communicative motives are most significant for first-year students as compared with older peers is, in our opinion, due to the prevalence in senior courses of professional, educational, cognitive, 
and creative self-realization motives.

Strengthening, with an increase in the course of study, professional motives is probably associated with the unformed cognitive interest of first-year students and uncertainty in the choice of profession in junior courses. In the third year in the curriculum, disciplines of vocational training appear and students have a desire to learn more about their future profession, to become good specialists. At the same time, it comes to the realization that they need knowledge to ensure the success of their future career.

Undoubtedly, first-year students are primarily concerned with fulfilling their debt to parents who pay for their education and school, which does not allow them to relax and be distracted by creative activities, and also to think about such serious topics as the problems of social development. Therefore, the motives of creative self-realization are characteristic mainly for senior students. In all likelihood, these circumstances can also explain the fact that for freshmen, the motive of avoiding failure comes to the fore, and it retreats to the last place for senior courses. In more advanced courses, when the period of adaptation to new conditions is over, foreign students begin to show individual creative qualities, and there is an improvement in interpersonal relations in the study group.

The importance of social motives for the first-year foreign students is related, to a greater extent, to the fact that they feel more responsible to their parents and the school, and as they mature, they realize that their future official position and level of material well-being depend on their studies.

\section{Conclusion}

Education of foreign citizens in a pedagogical university, according to natural science profiles, is quite popular for students from Central Asian countries. Educational work with foreign students both enriches the pedagogical experience of the faculty and also leads to the strengthening of multicultural relations and the creation of conditions conducive to the full personal development of foreign students and their successful integration in the educational space of the university.

Undoubtedly, national diversity in a higher education institution, on the one hand, makes the cultural environment of an educational institution richer, and on the other hand, it conceals the risk of interethnic micro-conflicts [24]. Therefore, an important condition for ensuring national security is the formation of interethnic and interfaith tolerance among students of the Faculty of Natural Science Education at the Chuvash State Pedagogical University named after I. Y. Yakovlev, which, in our opinion, should be carried out not only during sporting or socially significant events but also in the learning process.

Based on the survey, we can formulate the following conclusions and recommendations:

- The assessment by foreign students of the university and faculty management indicates a favorable social and pedagogical environment of the educational environment that has developed at the faculty and at the university as a whole;

- The lack of competence in special terminology used in the study of natural sciences was established. In connection with this fact, when the Russian language is taught to the foreign citizens at preparatory courses, it is necessary to take into account future students' training profiles;

- We revealed the desire of foreign students to individually engage in the Russian language and curriculum disciplines;

- Foreign students noted the theoretical orientation of education at the faculty. In this situation, it is necessary to pay close attention when selecting faculty members with practical skills to work with foreign students.

- The research found that the multinational education environment of the university attracts a large number of cultural and sporting events, which is positively evaluated by foreign students. This creates a positive emotional background that contributes to the formation of common values;

- In order to increase confidence in choosing a future profession among foreign students, the process of acquaintance with the professional activities of Bachelors of Pedagogical Education 
should be started in the first year, actively involving not only curators, but also senior students.

The study, in general, showed that the formation of foreign students - Bachelors of Pedagogical Education - takes place under conditions of changing motivations during the course of study. In this case, an important factor is the confidence in the correct choice of profession.

In conclusion, I would like to note that the city of Cheboksary, which is the capital of the Chuvash Republic, located in the European part of Russia, has a very real prospect of becoming a city attractive to foreign students. This is favored not only due to its economic and geographical location but also due to the well-established educational conditions. Foreign students who come from more than 30 countries of the world study at universities of the city. However, for successful integration of foreign citizens into the educational environment and for them to obtain the desired amount of knowledge, they must have strong motivation and successful completion of the adaptation process to new conditions.

\section{References}

[1] Bashir, S. (2007). Trends in international trade in higher education: Implications and options for developing countries (p. 98). Washington, DC: World Bank.

[2] Adnett, N. (2010). The growth of international students and economic development: Friends or foes? Journal of Education Policy, 25, pp. 625-637.

[3] Teichler, U. (2012). International student mobility and the Bologna Process. Research in Comparative and International Education, 7, 1, pp. 34-49.

[4] Nikolaeva, I. V. (2016). Influence of the Bologna process on the Russian education system. Services: Innovation and Quality, 22, pp. 8-22.

[5] Petsoldt, K., Sutyrin, S. F., \& Elkina, A. S. (2007). Competitiveness of the university in the context of the internationalization of higher education. Problems of the modern economy, 1. Retrieved from http://www.m-economy.ru/art.php?nArtId=1276.

[6] Pimenova, N. Y. (2006). On the strategy of promoting the Russian education market to the international market. Strategic University Management: Practice and Analysis, 1, pp. 17-23.

[7] Ministry of Education and Science of the Russian Federation. (n.d.). Study in Russia. Retrieved from https://studyinrussia.ru/why-russia/russian-education-in-figures/.

[8] Richard B. Freeman (2010). What does global expansion of higher education mean for the United States? In Clotfelter, C. (Ed.), American universities in a global market (pp. 373-411). Chicago: University of Chicago Press. DOI:10.7208/chicago/9780226110455.003.0012.

[9] Maria P. Cantu (2013). Three effective strategies of internationalization in American universities. Journal of International Education and Leadership, 3(3). Retrieved from https://files.eric.ed.gov/fulltext/EJ1136025.pdf.

[10] Chupina, V. A., \& Pleshakova, A. Y. (2015). Internationalization of the process of higher professional education: problems and vectors of development. Humanitarian Scientific Research, 11. Retrieved from http://human.snauka.ru/2015/11/12627.

[11] Altbach, P. (2004). Globalization and the university: myths and realities in an unequal world. Tertiary Education and Management, 1(10), pp. 3-25.

[12] Rami, M., Ayoubi, K., \& Massoud H. (2007). The strategy of internationalization in universities: a quantitative evaluation of the intent and implementation in UK universities. International Journal of Educational Management, 4(21), pp. 329-349. Retrieved from https://doi.org/10.1108/09513540710749546

[13] Ivanov, D. E., \& Egorova, L. D. (2014). Socio-cultural adaptation of foreign students as a problem of modern universities of Russia. Bulletin of Chuvash State Pedagogical University named after I. Y. 
Yakovlev, 3(83), pp. 122-127.

[14] Pogukaeva, A. V., Kobernik, L. N., \& Omelyanchuk, E. L. (2016). Adaptation of foreign students in a Russian university. Modern Problems of Science and Education, 3. Retrieved from http://scienceeducation.ru/ru/article/view?id=24651.

[15] Badmaeva, N. Ts. (2004). Influence of the motivational factor on the development of mental abilities. Ulan-Ude, Russia: VSSTU Publishing House.

[16] Pavlyukova, Y. V., \& Dryagalova, E. A. (2015). Features of social and pedagogical adaptation of foreign students in high school (on the example of Arab students in the center of pre-university training). Modern Problems of Science and Education, 6. Retrieved from http://scienceeducation.ru/ru/article/view?id=23732.

[17] Badzhaeva, L. V., \& Omurzakov, M. V. (2016). The problem of adaptation of foreign students in Russian universities (on the example of Kalmyk State University). In Pedagogy and Psychology: Actual problems of research at the present stage, collection of materials of the $X$ International Scientific practical conference (p. 5-7). Elista, Russia.

[18] Ilyin, E. P. (2000). Motivation and motives. SPb, Russia: Piter Publishing House.

[19] Chirkov, V. I. (1991). Motivation of educational activities. Yaroslavl, Russia: YarSU Publishing House.

[20] Mazitova, L. T. (2002). Social adaptation of foreign students: the example of universities in Bashkortostan. Ufa, Russia: Nauka.

[21] Modnov, S. I., \& Ukhova, L. V. (2013). Problems of adaptation of foreign students studying at a technical university. Yaroslavsky Pedagogical Gazette, 2(1), pp. 111-115.

[22] Ziyatdinov, A. M., Matukhin, E. L., Nketiya, D., Nyame, T. G., Sadykov, R. Al-Hilal, V. Dari Kori, R., \& Ziyatdinova, M. (2016). Actual problems of teaching foreign students in Russian higher technical educational institutions. In Actual problems of socio-economic and environmental security of the Volga region region, a collection of materials of the VIII international scientific-practical conference, pp. 303-306. Volgorgad, Russia.

[23] Goncharova, I. P. (2012). The problem of language training of foreign students-future doctors. In Professional linguistics education: materials of the sixth international scientific-practical conference (pp. 64-72). Moscow, Russia.

[24] Lebedeva, N. M., Tagarko, A. N. (2005). Tolerance in intercultural dialogue. Moscow, Russia: RAS. 